\title{
Pedicellate Spikelet Fertility in Big Bluestem from Eastern South Dakota
}

\author{
A. BOE, J.G. ROSS, AND R. WYNIA
}

\begin{abstract}
Within a nursery of big bluestem (Andropogon gerardii Vit.) from seed collections made in eastern South Dakota, $86 \%$ of the plants possessed fertile pedicellate spikelets. From 10 random culms of 462 plants representing 20 different collection sites, seed-bearing sessile and pedicellate spikelets were separated and weighed. A highly significant difference was found among sites for pedicellate spikelet seed yield. Fertile pedicellate yield was positively correlated $(r=0.69, P<0.01)$ with total seed yield of ten culms. Pedicellate spikelet caryopses were smaller than sessiles from the same plant, suggesting they were of inferior quality.
\end{abstract}

The inflorescence of big bluestem (Andropogon gerardii Vit.) possesses 2 types of spikelets at each rachis node. The sessile spikelets are usually perfect, while the pedicellates have been described as staminate or neuter (Hitchcock 1951, Gould 1968). However, Wheeler and Hill (1957) pointed out that the pedicellate spikelet "often contains a well-developed grain." Ross (1973) observed fertile pedicellate spikelets in nursery populations of big bluestem derived from South Dakota collections and noted that seeds from the sessile spikelets were much larger than from pedicellates.

Casady and Miller (1970) found genetic variation from pedicellate spikelet hermaphroditism in Sorghum bicolor L. populations. One population from China had $72 \%$ hermaphroditic pedicellate spikelets. Pedicellate spikelet caryopses were smaller and produced a greater percentage of abnormal seedlings than sessiles.

Big bluestem is a notoriously poor seed producer (Cornelius 1950); but since it possesses slightly more pedicellate than sessile spikelets, it is feasible that seed production could be substantially increased by increasing pedicellate spikelet fertility. The objectives of this study were to determine, within a nursery of eastern South Daota ecotypes, the frequency of occurrence and potential agronomic usefulness of plants possessing fertile pedicellate spikelets.

\section{Materials and Methods}

Big bluestem seeds collected in 1971 from 20 relict sites (hereafter referred to as sites) in eastern South Dakota were planted in a spaced-plant nursery at Brookings in 1972. Sites were assigned to whole plots at random and families were randomized within sites. A family consisted of plants obtained from seeds of a single plant. Replication was not possible because of the small numbers of seeds per plant in nature. To help compensate for lack of replication, a level uniform soil area was selected. Inflorescences were harvested in 1977 from 10 culms of 462 plants representing approximately 5 families from each of the sites. These were separated into sessile and pedicellate spikelets by hand screening through 1.2 by $9.5 \mathrm{~mm}$ holes. Pedicellate spikelets were awnless, glabrous, and more terete than sessiles and readily passed through the holes. Fertile spikelets were separated from steriles using a South Dakota seed blower.

Hierarchal analysis of variance was used to analyze the seed yield data. Since number of families and number of individuals within families were not equal for all sites, a computer analysis employing PROC NESTED (Barr et al. 1976) was used.

Caryopses were threshed from sessile and pedicellate spikelets of 15 plants from 5 random sites. Weights were obtained for 2 samples

\footnotetext{
Authors are assistant professor, professor, and graduate assistant, Plant Science Department, South Dakota State University, Brookings.

This research is a contribution from the South Dakota Univ. Agricultural Experiment Station, Brookings 57007 . The germplasm collection was supported by a research grant from Regional Project NC-7 through the Regional Plant Int roduction Station, Ames, lowa. Journal Paper No. 1770.

Manuscript received August 4, 1981
}

of 30 caryopses for both sessile and pedicellate spikelets from each of the 15 plants.

Phenotypic correlations between seed yield characters were made on an individual plant basis.

Germination tests were conducted on 2, 30-caryopses samples from sessile and pedicellate fractions of 4 random plants.

\section{Results}

Fertile pedicellate spikelets were obtained from $86 \%$ of the plants harvested. The range in fertile spikelet yield from 10 random culms for each plant was from nil to $2.78 \mathrm{~g}$ for the pedicellate compared to 0.15 to $9.20 \mathrm{~g}$ for the sessile. The grand means were 0.38 and $1.94 \mathrm{~g}$ for the pedicellate and sessile, respectively.

Highly significant differences among sites were found for total, sessile, and pedicellate spikelet seed yields (Table 1). Highly significant differences among families were found for total and sessile but not for pedicellate.

Table 1. Mean squares from analysis of variance of total, sessile, and pedicellate seed yields.

\begin{tabular}{lcccc}
\hline & \multicolumn{4}{c}{ Mean square } \\
\cline { 2 - 5 } Source of variation & $\mathrm{df}$ & Total & Sessile & Pedicellate \\
\hline $\begin{array}{l}\text { Among sites } \\
\text { Among families } \\
\quad \text { w1thin sites }\end{array}$ & 19 & $4.19^{* * 1}$ & $3.09^{* *}$ & $0.49^{* *}$ \\
$\begin{array}{c}\text { Among individuals } \\
\text { within families }\end{array}$ & 104 & $1.90^{* *}$ & $1.42^{* *}$ & 0.14 \\
\hline
\end{tabular}

${ }^{1 * *}$ Significant at the 0.01 level.

Highly significant positive correlations were observed between sessile and pedicellate $(r=0.47, P<0.01)$, sessile and total $(r=$ $0.97, P<0.01)$, and pedicellate and total $(r=0.69, P<0.01)$ spikelet seed yields from 10 culms.

Caryopses weight of sessile spikelets of 15 random plants from 5 sites was significantly greater $(P<0.01)$ than pedicellate spikelet caryopses weight from the same plants. Mean 30 caryopses weight of the sessiles was $43.1 \pm 1.8$ compared to $31.7 \pm 1.2 \mathrm{mg}$ for the pedicellates.

Germination tests indicated 78 and $89 \%$ germinability for pedicellate and sessile spikelet caryopses, respectively.

\section{Discussion}

These preliminary observations indicate that pedicellate spikelet fertility is common in eastern South Dakota big bluestem populations. Considerable variation for this trait was found among sites, suggesting that selection for increased pedicellate spikelet fertility may be possible based on inherent ecotypic differences.

Plants that exhibited high degrees of pedicellate spikelet fertility tended to be the highest total seed yielders based on 10 culms from each plant. Increasing pedicellate spikelet fertility in a breeding population could feasibly increase seed yields dramatically. Of course, the relationships of pedicellate spikelet fertility to other seed yield components, such as number of flowering culms and seed size, need to be determined.

Pedicellate spikelet caryopses tended to be smaller and more shriveled than sessiles, and, as might be expected, their germina- 
tion was somewhat lower. However, we did observe many plump, well-developed caryopses in the pedicellate fractions.

Previous taxonomic treatments (Hitchcock 1951, Gould 1968) have not indicated the occurrence of perfect pedicellate spikelets in big bluestem. Future treatments should note the occurrence of this character, particularly in eastern South Dakota ecotypes.

Because of its enormous potential for increasing seed yield, pedicellate spikelet fertility is being studied with the intent of incorporating it into a variety.

\section{Literature Cited}

Barr, A.J., J.H. Goodnight, J.P. Sall, and J.T. Helwig. 1976. A user's guide to SAS. SAS Inst. Inc. Raleigh, N.C.

Casady, A.J., and F.R. Miller. 1970. Inheritance of hermaphrodite pedicelled spikelets of sorghum. Crop Sci. 10:612-613.

Cornelius, D.R. 1950. Seed production of native grasses under cultivation in eastern Kansas. Ecol. Monogr. 20:3-29.

Gould, F.W. 1968. Grass systematics. McGraw-Hill.

Hitchcock, A.S. 1951. Manual of the grasses of the United States. USDAMisc. Pub. No. 200. 2nd ed. revised by Agnes Chase.

Ross, J.G. 1973. Domestication of warm season grasses native to. South Dakota. Proc. 22nd Western Grass Breeders Work Planning Conference. 23-24.

Wheeler, W.A., and D.D. Hill. 1957. Grassland Seeds. D. Van Nostrand Co., Inc. Princeton, N.J. 